\title{
Juridical Overview of The Financing of MSME Micro Capital Service Unit (ULaMM) Syariah
}

\author{
Nurhikma1, Ulya Atsani², Kieren Akbar \\ ${ }^{1}$ State Institute for Islamic Studies (IAIN) of Batusangkar, Indonesia \\ e-mail: nurhikma@iainbatusangkar.ac.id \\ ${ }^{2}$ State Institute for Islamic Studies (IAIN) of Batusangkar, Indonesia \\ e-mail: ulyaatsani@iainbatusangkar.ac.id \\ ${ }^{3}$ International Islamic University Malaysia, Malaysia \\ e-mail: kieren313@gmail.com
}

\begin{tabular}{|l|l|l|}
\hline Received: 12-03-2021 & Revised: 29-10-2021 & Accepted: 10-11-2021 \\
\hline
\end{tabular}

Abstract: This article is motivated by the special tasks carried out by the PT. Madani National Capital (PNM), which is only to carry out business activities to channel funds without making efforts to raise funds because this business unit is not a banking institution. The Micro Capital Service Unit (ULaMM) is a capital loan service for micro and small businesses accompanied by guidance to develop their business. UlaMM has been running business activities and providing financing services for the development of cooperatives, micro, small and medium enterprises. The agreement made by both parties was made in writing in accordance with POJK Number 16/POJK.05/2019 concerning the Supervision of PT. Permodalan Nasional Madani, Micro Capital Service Unit (ULaMM). This research uses descriptive qualitative method with data analysis used with descriptive analysis. Based on the method that has been used, it can be concluded that the agreement made is stated in writing in an agreement, this is in line with the provisions contained in POJK article 7 paragraph (2) which regulates that the financing service agreement must be made in writing. The agreement made is also in accordance with the provisions contained in Article 1320 of the Civil Code which regulates the legal terms of agreement.

Abstrak: Artikel ini dilatarbelakangi oleh tugas khusus yang dilakukan oleh PT. Madani National Capital (PNM) yang hanya melakukan kegiatan usaha menyalurkan dana tanpa melakukan upaya penghimpunan dana karena unit usaha ini bukan merupakan lembaga perbankan. Unit Layanan Permodalan Mikro (ULaMM) adalah layanan pinjaman modal untuk usaha mikro dan kecil disertai dengan bimbingan untuk mengembangkan usahanya.UlaMM telah menjalankan kegiatan usaha dan memberikan layanan pembiayaan untuk pengembangan koperasi, usaha mikro, kecil dan menengah. Kesepakatan yang dibuat oleh kedua belah pihak dibuat secara tertulis sesuai dengan POJK Nomor 16/POJK.05/2019 tentang Pengawasan PT. Permodalan Nasional Madani, Unit Pelayanan Modal Mikro (ULaMM). Penelitian ini menggunakan metode deskriptif kualitatif dengan analisis data yang digunakan dengan analisis deskriptif. Berdasarkan cara yang telah digunakan dapat disimpulkan bahwa perjanjian yang dibuat dituangkan secara tertulis dalam suatu perjanjian, hal ini sejalan dengan ketentuan yang terdapat dalam POJK pasal 7 ayat (2) yang mengatur bahwa perjanjian jasa pembiayaan harus dibuat secara tertulis. Perjanjian yang dibuat juga sesuai dengan ketentuan yang terdapat dalam Pasal 1320 KUHPerdata yang mengatur tentang syarat sahnya perjanjian.

Keywords: Legal Aspects. UlaMM, Sharia.

\section{INTRODUCTION}

greements or contracts are growing rapidly nowadays as a logical consequence of the development of business cooperation between business people. Many business collaborations are 
carried out by business people in the form of contracts or written agreements. Even in business practice there has been a growing understanding that business cooperation must be held in written form.

A written contract or agreement is the basis for business actors or parties to carry out a lawsuit if one of the parties does not carry out what has been agreed in a contract or agreement. Actually, legally, apart from a written contract, the parties or business people can make a verbal contract. However, a contract made orally carries a very high risk,

Society is a group of people who live together in an organized community. This happens because humans are zoon politicons (social beings). Humans as social beings, always interact with one another. That is, many new legal relationships arise in society where it arises because of urgent needs, especially those related to the socio-economic field.

So that the legal relationship can not cause conflict, then the parties then make the rules that are embodied in an agreement. This is in accordance with Apeldoorn's opinion which states that "agreements are one of the factors that help form law". An agreement is an act by which one or more people bind themselves to one or more other people (Article 1313 of the Civil Code). The agreement is regulated in book III chapter II of the Civil Code under the title Engagements born of contracts or agreements. Book III is open, it means that the provisions are only complementary (aanvulen recht). That is, as a complementary law the provisions in book III can be deviated by the parties to the agreement. (Outsourcing és mtsai., 2011)

In the field of Property Law, in the systematics of legal science, some are absolute and some are relative. The right to absolute property is regulated in Book II of the Civil Code, while the right to relative property is regulated in Book II of the Civil Code. The Law of Objects regulates the relationship between legal subjects and legal objects (objects) that give birth to material rights, while the Law of Engagement regulates the relationship between legal subjects and legal subjects, which gives birth to legal objects in the form of objects. (Rofifah, 2020)

\section{Covenant Principles}

a. The principle of consensualism, this principle can be stated in Article 1320 of the Civil Code which requires an agreement as a valid agreement. However, it should be noted that there are exceptions to the principle of consensualism, namely in real agreements and formal agreements that require submission or fulfill certain forms required by law. (Komariah, 2002, 173).

b. Principles of Pacta SunservandaThe theoretical basis for binding contracts is that the parties that are generally adopted in civil law countries are influenced by canonical law. Canon Law begins with the critical discipline that every promise is binding. This is where the principle of pacta sunt servanda was born. According to this principle, the agreement of the parties is binding as is law, as the parties who made it. (Ridwan Khairandy, 2004; 28).

c. The principle of freedom of contract, according to Rutten, civil law, especially contract law, is entirely based on the principle of freedom of contract. (Purwahid Patrik, 1986; 3) The principle of freedom of contract adopted by Indonesian law cannot be separated from the Open System 
adopted by Book III of the Civil Code, which is a complementary law that may be overridden by the parties making the agreement. With the principle of freedom of contract, people can create new agreements known in the Named Agreement and their contents deviate from the Named Agreement which is regulated by law (J. Satrio, 1993; 36). In other words, every agreement reached between the parties (consensus) can lead to an agreement or called consensuality. (Herlien Budiono, 2016; 12-13)

d. The principle of propriety, this principle is related to the provisions regarding the contents of the agreement, the arrangement of this principle is confirmed in article 1339 of the Civil Code, namely that agreements are not only binding on matters expressly stated in them, but also for everything which, according to the nature of the agreement, is required by law. propriety, custom or law. (M. Hasbi, 2009; 21)

e. The principle of balance is a principle intended to harmonize legal institutions and the basic principles of contract law known in the Civil Code based on the thoughts and backgrounds of individualism on the one hand and the way of thinking of the Indonesian nation on the other. (Herlien Budiono, 2010; 29)

\section{Terms of the Validity of the Agreement}

In article 1320 of the Civil Code, it has been determined that to be valid an agreement must meet the following requirements:
a. Agreement of the parties
b. The ability to make an engagement
c. A certain thing
d. A lawful reason. (Contract, 2012)
Covenant Elements

a. essentialia, very essential/important element in an agreement that must exist. This part is the nature that must exist in the agreement, the nature that determines or causes the agreement to be created.

b. natural, for a reasonable agreement if it is not set aside by both parties.

c. Accidentalia, elements of the existing agreement if desired by both parties. (Badrulzaman, 2001; 74)

In Indonesia, engagement is generally used as the equivalent of Dutch verbintenis and agreement as the equivalent of overeenkomst. There are also those who use the word agreement as the equivalent of verbintenis, while overeenkomst is used for the word agreement. In contemporary Islamic law, the term iltizam is used to refer to an engagement (verbintenis) and the term akad to refer to an agreement (overeenkomst). The last term, namely akad, is actually a fairly old term used since classical times so it is very standard. While the first term, namely iltizam, is a new term to mention the engagement in general, in the sense that the engagement as a whole in modern times is called the term iltizam or engagement.(Amalia, 2013).

In general, the meaning of "transaction" is often reduced to a sale and purchase agreement between the parties who agree to it. Whereas in a juridical perspective, the terminology of the transaction is basically the existence of an engagement or legal relationship that occurs between the parties. Therefore, the existence of legal provisions regarding engagements remains binding despite changes in media and changes in transaction procedures. (Suhartono, 2010)

Likewise with the legal relationship between the Sharia Micro Capital Service 
Unit (UlaMM) and the customer, the agreement between ULaMM Sharia and the customer is stated in written form containing the rights and obligations of each party. One of the contracts used in the agreement made is the contract Murabahah, where UlaMM applies the concept of buying and selling by explaining the cost of purchase and the added profit and agreed upon by both parties. In muamalah fiqh, it has been explained that in buying and selling transactions, the pillars and conditions must be met, namely the presence of a buyer, a seller, the object of sale and purchase and the consent of kobul. In practice, murabahah financing is usually always included with the wakalah contract. (Rima Nurhayati, 2020)

With the agreement in the distribution of funds to the community, of course, it can help increase Micro, Small and Medium Enterprises (MSMEs) so that existing MSMEs can develop and can play a role in the growth of the national economic sector (Suhardjono, 2003). Economic empowerment is a political commitment to gradually change the conglomerate economic paradigm by growing lower-level economic activities. (Zulkarnain, 2003)

The purpose of empowering small businesses is to grow and improve their ability to be independent and develop into medium-sized businesses. According to Law Number 20 of 2008 concerning Small, Micro, and Medium Enterprises article 1 paragraph 8 states that empowerment is an effort made by the government, the business world and the community in the form of growing the business climate, fostering, and developing so that small businesses are able to grow and strengthen he became a strong and independent business. (Wardani, 2013)
The Sharia Micro Capital Service Unit (ULaMM) is part of the State-Owned Enterprises (BUMN), formed by the government with the same aims and objectives, namely in the context of empowering micro and small businesses. State-Owned Enterprises (BUMN) are one of the actors in economic activities in the national economy based on economic democracy and have an important role in the implementation of the national economy in order to realize the welfare of the community. (Point \& Gunndi, 2014)

BUMN has established an economic institution that can mediate the need for funds for people who want to develop the real sector, namely the Sharia Micro Capital Service Unit (ULaMM). This unit is a service from PT. Civil National Capital (PNM) which has a special task of empowering MSMEs. However, the activities carried out by UlaMM Syariah are only lending or channeling financing and do not collect funds from the public because this business unit is not a banking institution. (Hidayatullah, 2011)

The definition of small business according to the Law of the Republic of Indonesia Number 20 of 2008 concerning Micro, Small and Medium Enterprises. Small business is a productive economic business that stands alone, which is carried out by individuals or business entities that are not subsidiaries or branches of companies that are owned, controlled, or become part either directly or indirectly of a medium or large business that meets the criteria of a small business as referred to in the Law. the law. (Tambunan, 2009)

In terms of the agreement in the financing agreement between the debtor and PT. Permodalan Nasional Madani (Persero) Micro Capital Service Unit (ULaMM) is made by both parties in 


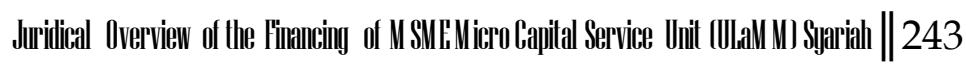

accordance with the legal terms of an agreement. (Pajari, 2019 Vol 3 No 2). Usually, in channeling financing to the public, ULaMM Syariah does not directly provide financing proposed by customers, but ULaMM conducts a survey first of its customers' businesses. After seeing the survey results, customers can only be given financing based on the customer's business conditions. (Rahmadina, 2020, Vol 5. No. 1)

In terms of business activities, it is very much different when compared to other financial institutions because there is no process of raising funds, only the process of distributing funds, therefore of course the agreement made by both parties will automatically create a legal relationship between the parties.

\section{RESEARCH METHODS}

The type of research used in this research is field research, which is a research that is carried out intensively, in detail and in depth on a particular object by studying it as a case. The qualitative research referred to here is to describe the Juridical Review of MSME Financing at ULaMM Syariah PT. PNM Persero. The data source consists of primary data sources. The method of retrieval of this data source is by conducting direct interviews with the Head of ULaMM Syariah PT. PNM Persero, employees of ULaMM Syariah PT. PNM Persero, which has provided information and data regardingMSME financing in Sharia ULaMM, whilesource Secondary data were obtained from libraries, internet, text books, articles from websites and some relevant literature.

\section{RESULT AND DISCUSSION}

Financial Services Authority Regulation Number 16/POJK.05/2019 Concerning the Supervision of PT.Permodalan Nasional Madani in Chapter III Business Operations Article 7 explains the provisions regarding all financing service business activities between companies with customers must be stated in The financing service agreement and the Financing Services agreement as referred to in paragraph (1) must be written down and contain various information that has been determined. based on the legal facts that exist in the field, the agreement made by UlaMM Syariah with the customer is set forth in a secret manner written fig this is realized at the time of signing murabahah bil wakalah contract.

\section{Financing Services Agreement}

The financing service agreement contained in POJK article 7 paragraph (1) has been implemented in the murabahah bil wakalah contract.

Murabahah is a sale and purchase transaction in which ULaMM is the provider of goods and the customer is the buyer of goods, which can then be paid in installments or in installments. The bank acts as the seller, while the customer acts as the buyer. The selling price is the bank's purchase price from the supplier or supplier plus profit or margin. Both parties must agree on the selling price and payment term. The selling price is stated in the sale and purchase contract and if the agreement has been agreed, the agreement may not change during the validity of the contract. Murabaha is always associated with installment payments. In this transaction, the goods are delivered after the contract, while the payment is made in installments. 
The application of murabahah financing that exists in Sharia UlaMM in fact in terms of purchasing or supplying goods needed by customers turns out to include a wakalah contract in it. Wakalah in language can be interpreted as the transfer of power and authority from the sharia UlaMM to the customer as the recipient of the authorization to purchase goods. It can be seen that there is a difference between practice in murabahah and theory, namely the inclusion of wakalah. Actually in murabahah there is no wakalah because wakalah is a separate contract from murabahah. This contract is a multiple contract, the bank authorizes the customer to use the existing funds in accordance with the needs of the business being undertaken.

Murabahah bil wakalah contract contains the type of disbursement of funds, the number and date of the agreement, the identity of the parties, the amount of financing, the date of payment and the value of the financing installments, the period and rate or share. financing results, type of collateral (if there is collateral), mechanism in the event of a dispute and the selection of the place of dispute resolution, provisions regarding the rights and obligations of the parties; and provisions regarding fines/ta'zir (if any) fines/ta'zir).

Article 1320 of the Civil Code, Conditions for a valid agreement

\section{a. Agree}

Agree is an absolute condition when the parties carry out the agreement. The logical consequence of this agreement is that without an agreement the agreement will not be legally valid. The following describes the form of this agreement, illustrated from the initial process when the customer intends to submit an application to the stage where the customer and the bank realize an agreement by signing the prepared contract agreement:

1) Customers come directly to ULaMM Syariah, fill out fmicrofinance application form and at the same time submit the specified requirements

2) ULaMM Syariah will check using the customer's ID card through the BI Checking application and the Debtor Internal System (SID), which aims to view the customer's previous financing history.

3) Then AO (Account Officer) and KKU (Head of ULaMM Office) will conduct a survey to the customer's business, where this survey is to find out the actual situation of the customer. In assessing customers, AO (Account Officer) and KKU (Head of the ULaMM Office are based on the 5 C 9 principle (Character, Capacity, Capital, Condition, Collateral)

4) $\mathrm{AO}$ (Account officer) will input data from survey results with appropriate or inappropriate information. If feasible, the application will be reviewed and will provide recommendations

5) the application for microfinance by AOM (Micro Account officer) is submitted to the branch.

6) After the approval of the customer's microfinance proposal is approved by the branch, the KKU (Head of the ULaMM Office), AOM (Micro Account officer) and KAM (Micro Finance and Administration) will make a financing commitment (akad) with the customer.

7) After the contract is explained, the customer will signing a murabahah bil wakalah contract (buying and 
selling with support/deposit) in accordance with applicable policies and accepting the proposed collateral and submitting a Sharia Financing Disbursement Note (NPPS) based on the approved financing contract and guarantee documents submitted to supporting including costs and reserve funds for $1 x$ (one) installment.

8) Next, the financing disbursement process is carried out by KAM (Micro Finance and Administration) and the Finance and Operations Manager by transferring to the customer.

b. Engagement Skills(om eene verbintenis aan te gaan)

Article 1329 of the Civil Code states that everyone is capable. Then Article 1330 of the Civil Code provides an exception with the explanation "there are some people who are not capable of making agreements", namely: People who are not yet adults, People who are placed under guardianship (curatele or conservatorship). However, the parties who carry out the agreement with the Sharia Ulamm are people who are classified as legally competent, this can be seen in one of the requirements for customers who can apply for customers who are 21 years old.

\section{c. A Certain Thing}

Article 1333 of the Civil Code paragraph 1 states that an agreement must have the subject matter (zaak) of which at least the type can be determined. An agreement must have a subject matter. Therefore, the object of the agreement in Sharia Ulamm is goods. Although the customer submits an application for business financing by stating the nominal financing, in the contents of the agreement the parties use a murabahah bil wakalah contract. The Ulamm party as the giver of power and the customer as the recipient of the power of attorney who will later use the funds for their business needs.

d. The cause (cause) of the lawful law

The agreement made must not promise anything that is prohibited by law or which is contrary to the law, the values of decency or public order, this is in line with the business activities carried out because sharia Ulamm will only channel financing to customers. which has a lawful business and does not contain elements of maisir, gharar, and usury).

According to author's analysis the first and second terms are subjective terms because they involve the people or parties who make the agreement. If the subjective conditions are not met, then the agreement that has been made can be canceled. The third and fourth conditions are called objective conditions, because they are related to the agreement made. If these objective conditions are not met, then the agreement made will be null and void, meaning that the agreement made is considered to have never existed.

\section{CONCLUSION}

The implementation of the agreement carried out by sharia UlaMM is in accordance with the provisions contained in Article 1320 of the Civil Code, the provisions contained in this article are regarding the valid terms of agreement, namely agreement for those who bind themselves, agreement for those who bind themselves, the skills of the parties, a certain things and legal causes. The agreement that was held was also in accordance with the provisions contained in POJK Number 16/POJK.05/2019 Concerning the Supervision of PT. Permodalan Nasional Madani Article 7 
regulates financing activities. The agreement made by both parties is in accordance with the established rules. It is hoped that UlaMM can foster various business fields undertaken by customers who apply for financing so that existing businesses become more developed and are also able to create new jobs.

\section{REFERENCES}

Ahmad, S. (2016). MSME Empowerment Maximization Strategy Through Sharia Micro Capital Service Unit (ULAMM) PT. Madani National Capital (Persero) Demak. Holy: STAIN Holy.

Wardani, H. K. (2013). The Role of the Cooperatives and SMEs Office in empowering Small and Medium Enterprises in the City of Malang. Journal of Public Administration (JAP), 214-215.

Hidayatullah, M. S. (2011). Strategy of the Sharia Micro Capital Service Unit (ULAMM) of PT. Civil National Capital (Persero) in Empowering MSMEs. Jakarta: Syarif Hidayatullah State Islamic University.

Pajari, Z. (2019). Debtor Default in Financing Agreement at Pt. Madani National Capital (Persero) Micro Capital Service Unit (Ulamm). EJournal of Fatwa Law Faculty of Law, Tanjung Pura University, 3 (2).

Programme, M. U. (2017). Division of education and training center. Jakarta: MU-TP.

Rahmadina, R. M. (2020). The Effect of the MEKAAR PNM Program on the Income of the Poor in Campalagian District. J-ALIF Journal of Islamic Economics and Social Law Research, 5 (1), 12.
Nurhayati, R. (2020). Fiqh Muamalah Analysis of the Implementation of Murabahah Financing at the PT.PNM Syariah Mekar Program in Tanjung Kamuning Village, Garut. Sharia Economic Law Proceedings, 451.

Suhardjono. (2003). Credit Management: Small and Medium Enterprises. Yogyakarta: AMP YKPN.

Tambunan, T. T. (2009). MSMEs in Indonesia. Jakarta: Ghalia Indonesia.

Titik, T., \& Gunandi, W. I. (2014). State Administrative Law and Indonesian State Administrative Court Procedural Law. Jakarta: Kencana Pranada Media Group.

Zulkarnain. (2003). Building People's Economy. Yogyakarta: Adicita Karya Nusa. 